\title{
Marketing In Greece: The Reasons Of Its Underdevelopment
}

Orlando Rivero, D.B.A., Carlos Albizu University, USA, Vice-President, JDT Management Consultants, USA John Theodore, Ph.D., D.B.A., Ph.D., CMC, President, JDT Management Consultants, USA

\begin{abstract}
The purpose of this article is to demonstrate that marketing in Greece is underdeveloped because the nation does not have an adequate number of private corporations due to insufficient industrialization. Advanced marketing practices are the result of the corporate form of business. Industrialization in Greece was followed by a rapid shift to post-Fordism in the late 1980s which had a tremendous impact upon the lack of opportunity for merging small organizations into larger ones needed for the creation of the corporate form of business and the formation of new and larger organizations in the corporate form. The corporate form of business is large, provides in abundance, the factors of production, and has highly developed functional units-production, marketing, finance, and human resources. Clearly, the majority of Greek business organizations are small, thus disallowing for formation of an infrastructure that leads to the development of marketing through the effective and efficient use of all the factors of production.
\end{abstract}

Keywords: Industrialization; De-Industrialization; Corporate Form Of Business; Organizational Development; Organizational Structure; Mergers; Development Of Marketing; Strategic Marketing Plans; Systematic Analysis; Marketing Initiatives; Strategic Vision; Marketing Objectives; Small And Medium Size Firms

\section{INTRODUCTION}

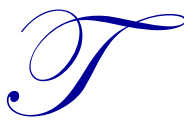

he purpose of this article is to demonstrate that marketing in Greece is underdeveloped because the nation, due to its limited industrialization, does not have an adequate number of private corporations that sustain and develop the functional unit of marketing.

\section{THE INDUSTRIAL SECTOR AND POST FORDISM}

Industrialization is the process of coordinating materials, persons, and machines to create finished products for the satisfaction of human needs. Industrialization necessitates a certain degree of economic development in order to take place (Theodore, 2011).

The Greek economy remained agricultural until the 1960s during which period industrial development started. Lamentably, the process of industrialization was slow due to the fact that the country did not have qualified business entrepreneurs and professional managers capable of supporting the developmental process (Theodore, 2012). In 1981, Greece entered into the European Economic Community (EEC) and became subject to the Community's economic and social regulations. The private sector in the economy began to gain ground and the Greek economy started to become largely dependent on the private sector, resulting in more privatization whose impact had a positive influence on business (Kavali, Tsokas \& Saren, 2001, p. 95). It should be noted that investments in manufacturing from developed nations inside and outside the European Union have been limited and some experts indicate that the entrepreneurial inclination of the Greeks is toward commerce - not manufacturing (Theodore, 1991). Since the 1990s, the Greek economy has had combined relatively strong economic performance (rapid GDP growth rate and strong productive growth) with a very weak performance on many other fronts, ranging from poor labor/product market institutions and low competitiveness to poor environmental protection (Mitsopoulos \& Pelagidis, 2007, p. 246). 
Industrialization was followed by a rapid shift to post-Fordism in the late 1980s, well before a culture of contractual relationships and attendant modes of social solidarity were widely developed (Petmesidou, 2005, p.120). This event had a tremendous impact on the lack of opportunity for merging small organizations into larger ones, thus creating the corporate form of business and the formation of new and larger organizations in the corporate form. Deindustrialization precipitated the manufacturing value-added share to GDP to decline from around 20 percent in the mid-1970s to less than 13 percent in the late 1990s (Bruton, 2006).

\section{THE CORPORATE FORM OF BUSINESS IN PRIVATE ENTERPRISES}

Corporations are one of the three legal forms of enterprise - proprietorships, partnerships, and corporations. Industrialization precipitated the development of corporations because it demanded large-scale enterprises and largescale capital (Bakan, 2004). Only the corporate form of business provides these elements due to its broadly distributed ownership, limited liability, and the ability to attract investors by offering ownership (stocks) at reasonable prices.

Furthermore, the process of de-industrialization caused the decline of the formation of new corporations and the inability of existing ones to grow in size and strength. The economy has been traditionally composed of a very large number of small private organizations. Statistical data in the early 1960 s indicated that in $1959,52 \%$ of all enterprises had fewer than nine persons employed; $27 \%$ of the enterprises had from 10-19 persons employed, $14 \%$ of the enterprises had 20-29\%, and .7\% had more than 50 persons employed (Theodore, 1991). A recent study conducted on Greece suggested that most small- and medium-size firms employ approximately $74 \%$ of the workforce within the private sector, which contributes to most of the working population in the country (Eurostat, 2010b)._According to the European Union (EU) calculations, a small-size firm in the EU is primarily made up of 50 employees, compared to a medium-size firm that has a maximum of 250 employees (Commission Recommendation, 2003).

The structure of the economy is marked by very few large enterprises and very many microfirms and small firms (Featherstone \& Papadimitriou, 2008). Most business organizations remain small and play a limited role in the Greek economic life, whereas large-sized enterprises, although comprising only $1 \%$ of the total number of firms (in all sectors), play a vital role in the Greek economy, mainly because of exports and the development of its stock market (Voulgaris, 2002, p.1380).

Innovation in production and marketing is absent in private enterprises and the country is lagging behind in the adoption/introduction of innovations and the development of business networks (Mavridis, 2002 p. 21).

\section{MARKETING IN GREECE}

Marketing has to do with the processes of creating, communicating, delivering, and exchanging offerings that have value for customers, clients, partners, and the society at large (Baker, 2008). Converse (1945) suggested that the theoretical development of early marketing was compared to the development of the atomic theory because of its uniqueness. In advanced economies that are characterized by the development of modern industrialization, marketing continues to evolve and the functions of marketing have been expanded during the last thirty years and have been included in the overall business strategy of advanced organizations (Theodore, 1993). A strategic marketing plan involves a systematic analysis of both short- and long-term objectives as they relate to marketing initiatives. This allows organizations to cultivate a strategic vision to expand their marketing objectives. Although establishing a strategic marketing plan is time-consuming and expensive, it is largely an investment for the future (Quinn, 1980).

Greek private enterprises that are mainly small- and medium-size proprietorships and partnerships are incapable of creating and maintaining strategic marketing plans that are found in the corporate form of business. Therefore, modern strategic marketing practices and theories cannot reach their optimal level of success in Greece compared to the more developed states in the European Union. For this reason, the owners of such firms are accustomed to face-to-face personal relationships which they consider as the best tactic for marketing penetration (Carson \& Gilmore, 2000). 
In addition, marketing strategies are not considered by the owners and managers of small- and medium-size organizations as a vital component of operating their organizations (Media Services, 2009). Also, organizational strategic plans are not considered a necessity for the existence and development of small- and medium-size firms due to the myopic mentality of their owners and managers who are, in most cases, members of the family of the owners. It has been noted that some small- and medium-size organizations are implementing limited marketing plan initiatives, but the decisions taken pertinent to such plans are made haphazardly by either the owners or their managers who do not have the expertise to make these kinds of decisions (Carson \& Gilmore, 2000).

Furthermore, the underdeveloped business and managerial mentality of the owners and managers of Greek business firms hinders their organizations' development and profitability expectations. This has led to the neglect of the role of strategic marketing initiatives; marketing is limited to mainly monitoring budget expenditures and not having a short- or long-term plan that focuses on brand awareness (Carson \& Gilmore, 2000).

Foreign and European Union corporations are reluctant to do business in Greece because of the backward business mentality entrepreneurs and managers have in that country. In the past, medium- and large-size foreign corporations have attempted to penetrate into the Greek economy, but they have been unsuccessful because the Greek small- and medium-size organizations dominate most of the business organizations and entry into the Greek market is difficult to attain (Theodore, 2012). Therefore, the growth and development of marketing through comprehensive marketing strategic management plans and implementations emanating from more developed nations cannot take place (Baker, 2010).

\section{RECOMMENDATIONS FOR MARKETING GROWTH AND DEVELOPMENT}

The authors of this article propose the following recommendations for the improvement of the marketing function in private Greek enterprises:

1. The creation of more private organizations in the corporate form of business in order to have larger organization size and develop all their functional units, including marketing

2. Mergers of small- and medium-size organizations to attain larger organizational size and develop all the functional units, including marketing

3. Establish marketing class curricula to assist students with basic everyday marketing needs, particularly in colleges and universities

4. Establish a partnership among Greek colleges and universities in order to form mentorship workshops/programs to assist small- and medium-size organizations owners and managers to have a better understanding of current marketing functions and theories

5. Institute partnership-driven initiatives among major United States and European Union corporations to assist the Greek small- and medium-firms with their marketing initiatives to promote their products and services

6. Allow the entrance of European Union and foreign medium- and large-size corporations to enter into the Greek market and contribute to the growth and development of the marketing function through their advanced expertise, knowledge, and practices

7. Monitor and review by small- and medium-size organizations emerging marketing trends found on the Internet and in traditional publications in order to apply marketing penetration and consequently maximize their return on investment

\section{CONCLUSIONS}

The underdeveloped state of the marketing function in Greece is due to the lack of the corporate form of business because industrialization in the country is limited.

Marketing developmental improvements can take place through the growth of small- and medium-size organizations, the creation of more domestic corporations, allowing the entrance of European Union and foreign corporation into the Greek market, placing emphasis on marketing curricula in colleges and universities, increasing marketing research and development, providing partnerships between colleges/universities and business 
organizations, and conducting effective and efficient monitoring and reviewing of international marketing trends by using conventional and electronic media.

\section{AUTHOR INFORMATION}

Dr. Orlando Rivero is the Director, Business Department (School of Business) at Carlos Albizu University. Dr. Rivero serves as the chief learning officer directing the administration, policies, integrity, program, and personnel of the instructional programs. Dr. Rivero is also the vice-president of JDT Management Consultants in Clearwater, Florida, specializing in management, organization, strategy, international business, human resources, organizational development, and educational administration. He earned his Doctoral degree in Business from Argosy University and completed his Master of Public Administration degree at Nova Southeastern University. Dr. Rivero's primary research focus is on public Administration, leadership, management, and effective communication. E-mail: orivero01@yahoo.com (Corresponding author)

Dr. John Theodore is the holder of a Ph.D. degree in Administration and Latin American Studies from the University of Kansas; a Ph.D. in Management from the Aristotelian University in Greece, European Union; and a D.B.A. in International Business from the University of South Africa. He has been teaching and consulting for four decades domestically and internationally. He is a visiting professor in various foreign universities. Dr. Theodore is the president of JDT Management Consultants in Clearwater, Florida, specializing in management, organization, strategy, international business, human resources, organizational development, and educational administration. He is a certified management consultant (CMC) certified by the Institute of Management Consultants in Washington, D.C. E-mail: jdtheodore@tampabay.rr.com

\section{REFERENCES}

1. Bakan, J. (2004). The corporation: The pathological pursuit of profit and power. New York, NY

2. $\quad$ Baker, M. (2008). The Strategic Marketing Plan Audit 2008. ISBN 1-902433-99-8

3. Bruton, J. (2006). The European Union. Political, social, and economic cooperation. Greece. Philadelphia. Mason Crest Publishers.

4. Carson, D and Gilmore, A (2000). Marketing at the Interface: Not "what" but "how", Journal of Marketing: Theory and Practice, pp 1-7

5. Commission Recommendation (2003). 203/361c/EC of 6 May 2003 concerning the definition of micro, small and medium-sized enterprises, Official Journal I. 124 of 20.05 .2003

6. Converse, P.D. (1945) 'The Development of the Science of Marketing - An Exploratory Survey', Journal of Marketing 10 (July): 14-23.Marketing: Theory and Practice, pp 1-7

7. Eurostat (2010b) key figures on European Business, Luxembourg: Publications Office of the European Union.

8. Featherstone, K. \& Papadimitriou, D. (2008). The Limits of Europeanization. Reform Capacity and policy in Greece. Houndmills. Palgrave Mcmillan.

9. Kavali, S., Tzokas, N., \& Saren, M. (2001). Corporate ethics: An exploration of contemporary Greece. Journal of Business Ethics, 30, 87-104.

10. Mitsopoulos, M., \& Pelagidis, T. (2009, July-August). Economic and social turbulence in Greece: The product markets are a no-brainer, the labour market is not. Intereconomics, 246. doi: 10.1007/s/10272-009$0302-2$

11. Media Services SA (2009). An organization that conducts research on advisement spending. http://media.mediaservices.gr .

12. Quinn, J. (1980) Strategies for change|Strategies for change: Logical Incrementalism, Irwin, Homewood Il

13. Petmesidou, M., \& Polyzoidis, P. (2005). The 'Social Quality' perspective in Greece. European Journal of Social Quality, 5(1/2), 119. Retrieved from Academic Search Complete database.

14. Theodore, J. (1991). The development of managerial practices in selected nations in the world. Edina, MN: Alpha Editions of Burgess Publishing Co.

15. Theodore, J. (1993) The development of managerial practices in selected nations in the World: Edina, MN. Alpha Editions/A Division of Burgess Publishing Co. 
16. Theodore, J. (2011). Culture and the development of management: An international example. Richmond, CA. Lyseis Public Policy Publishing, an Imprint of Concrescent LLC

17. Theodore, J. (January, 2012). The Lack of industrialization, the limited number of private corporations, and the retardation of management in private business enterprises in Greece. March/April 2012 issue of the Journal of Business Case Studies (Volume 8, Number 2. 
NOTES 